\title{
The Maltese Electorate Turns a New Leaf? The First European Parliament Election in Malta
}

\author{
Roderick Pace
}

\begin{abstract}
Malta's first European Parliament election was as hotly contested as the national elections. Turnout was third highest in the EU. The traditionally pro-EU Nationalist Party in government secured only two of the five seats contested, while the Opposition MLP, which up to last year opposed membership, took the other three. Since November 2003, the MLP has changed course on Europe and has joined the Party of European Socialists. Voter participation and a revealed preference towards candidates with Europeanist credentials show that support for EU membership has solidified, as supported by public opinion surveys. Support for the EU has increased from just under 53 per cent to around 80 per cent, enabling Malta to steer a steadier course in the EU.
\end{abstract}

Keywords: Malta; European Election; European Parliament; EU Enlargement; Election 2004

An opinion poll conducted for The Sunday Times of Malta, Malta's biggest circulation newspaper, published on 6 June 2004, showed that 84 per cent of voters intended to vote in Malta's first election to the European Parliament. Actual turnout on 12 June was a little above 82 per cent. Hence, this particular forecast on voter turnout was accurate but the election result was nevertheless surprising in many ways. The governing Nationalist Party (NP), which has consistently supported EU membership, gained two of the five seats. Its rival, the Malta Labour Party (MLP) - which up to April 2003 had strongly campaigned against membership-elected three MEPs. Malta's Green party, Alternattiva Demokratika (AD), which also supported EU membership and had campaigned shoulder to shoulder with the governing Nationalist 
party in the EU membership referendum campaign, produced an exceptionally good showing, but failed to secure its only candidate's election. Instead, its inroads into the NP's traditional vote helped the MLP elect its third seat. National issues dominated the debate. The most salient were unemployment, the environment and overall government performance.

Since losing the referendum and general election in 2003, the MLP has changed its policy stance on Europe. The first signs of this change appeared when it joined the Party of European Socialists (PES) as a full member in November 2003. The MLP's new stand on the EU was encapsulated in what its leader Dr Alfred Sant told The Sunday Times of Malta in an interview on 1 June 2003: 'What we believe about EU accession is now immaterial. The thing has been decided and we face a new reality now. This is not a question of changing our minds but of accepting this new reality'. In a motion approved by the Party's General Conference in November 2003, the MLP pledged to work within the $\mathrm{EU}$ and to do its utmost within the realm of possibilities available to it to counter all the negative effects that could result from the membership agreement.

EU membership has been a hot political issue for some time. It was first proposed by the Nationalist Party in the 1960s and reiterated more strongly in 1979 when the UK military bases were shut down in a Malta then governed by the MLP led by Dom Mintoff. Malta applied to join the EU in July 1990 but then suspended the application in 1996 when the MLP returned to government. An early election in 1998 won by the NP led to a reversal of this policy and the reactivation of the application. With negotiations concluded in 2002, a referendum was held on 8 March 2003. On a 90.9 per cent turnout, 52.9 per cent voted for membership, 45.7 per cent voted against and there were 1.5 per cent invalid ballot papers (see SESP Volume 9, Number 3). The MLP claimed that it had 'won the referendum' and that it would only accept membership if this was decided by the people in a general election, whereupon an election was held on 12 April 2003 which was again won by the Nationalist Party with a majority of just under 52 per cent.

These events indicate that EU membership was favoured not only by Maltese 'floating voters', but also by a sizeable minority of traditional MLP supporters. The defection of some of the latter must have been crucial in helping the 'Yes' campaigners secure a positive referendum result. An opinion poll published in The Sunday Times of Malta on 1 June 2003, two months after the election, indicated that 81.3 per cent of respondents wanted the MLP to embrace membership. This revealed that support for membership ran deeper then the ballot results showed and that perhaps the intense MLP-PN rivalry may have created an aberration concerning its extent. Significantly, the level of support for the EU indicated in this survey is not very different from the 82 per cent who actually voted in June 2004.

This article seeks to discuss Malta's first election to the European Parliament, held on 12 June 2004, to identify the main issues of the campaign and to analyze the possible reasons for the strong turnout, which was the third highest in the EU. This analysis will be made against the background of the Maltese political and electoral 
systems. Another question that this article seeks to answer is whether the Maltese EP election signals a major shift in Maltese support for the EU, from a low positive vote nearly verging on euroscepticism (53.4 per cent voted for membership in the 2003 referendum) to a more solid pro-EU one?

\section{The Electoral System and Main Results}

Whereas in national elections the territory of the islands of Malta and Gozo is divided into 13 electoral districts of more or less equal size, with Gozo constituting one district, for the election to the European Parliament, Malta and Gozo were merged into a single electoral district. Nevertheless, the proportional system based on the single transferable vote (STV) used in national and local elections was retained. A special electoral register was prepared for the EP election, which included all Maltese nationals eligible to vote in elections as well as EU nationals resident in Malta. In all there were 304,283 eligible voters. Twenty-seven candidates contested the five EP seats allocated to Malta. The main political parties, namely the governing NP and the Opposition MLP, fielded eight candidates each while $\mathrm{AD}$ fielded one. The other ten contestants consisted of independents and single-issue candidates, five of whom stood in the name of new political parties, notwithstanding the fact that they lacked the organizational structures to support this claim.

The threshold for electing a seat to the EP, referred to as the 'quota', was 40,954 votes. The quota is established by dividing the number of valid votes by the number of seats plus one and adding one more vote to the result. Only one candidate, Simon Busuttil, representing the NP (EPP) managed to achieve-and in his case even surpass-the quota. The MLP polled 118,983, the NP 97,688 and AD's only candidate, Prof Arnold Cassola, Secretary of the Green Group in the EP, obtained 22,938 first preference votes. The other 6,113 votes were polled by the other candidates. As a share of valid votes cast, the MLP obtained 48.4 per cent, the NP 39.8 per cent and AD 9.3 per cent. Following the publication of the election result, the MLP claimed it was first party. As already mentioned, the turnout in Malta was the third highest in the EU of 25 member states. It was only exceeded in Belgium and Luxembourg. However, while voting is obligatory in the latter two member states, it is not so in Malta. Many factors could have encouraged Malta's high turnout.

First, turnout in Maltese general elections is traditionally high, indeed one of the highest in the free world, averaging more than 95 per cent, though it tends to be much less in local elections. The data shown in Table 1 show valid votes cast as a percentage of registered voters have always surpassed the 95 per cent mark in three of the last four general elections. Although the election to the European Parliament should be treated differently from national and local elections, nevertheless, many of the factors at work in the former were also present this time. The most important factor in this respect is the capacity of the two main political parties to mobilize voters. Both parties are very well organized and deeply involved in the media. The Catholic Church, which still enjoys a lot of influence though this has been declining steadily over the years, also 
Table 1 Participation in Maltese Elections: Valid Votes Cast as a Percentage of Registered Voters

\begin{tabular}{lc} 
Year & National Election \\
\hline 1992 & $95.3 \%$ \\
1996 & $95.3 \%$ \\
1998 & $94.1 \%$ \\
2003 & $95.8 \%$ \\
\hline
\end{tabular}

strongly appealed to voters to exercise their right to vote. Finally, the EP election was the first of its kind in Malta. Hence, the novelty of the EP election may also have encouraged more people to vote in Malta. Of course, if this were the case, then the Maltese election would differ markedly from many of those which took place in the other new EU member states, where voter participation was disappointingly low. This trend has to be watched and analyzed in future EP elections.

When all is considered, there are two major factors for Malta's high turnout: the highly competitive and polarized nature of Maltese politics and the fact that underlying support for the EU has been much stronger than voting results (in the 2003 referendum and election) seem to indicate. Indeed, polarization and party loyalty seem to create aberrations concerning the real thrust of public opinion, which appears to be better captured by opinion polls.

\section{Does the Maltese Political System Confound the Theory?}

In 1964, Maurice Duverger articulated what has become known as 'Duverger's Law', namely that a majority vote on one ballot is likely to lead to a two-party system, while the proportional system produces a multi-party system. The Maltese political system appears to nullify this law. Although the Maltese system is based on a proportional system of voting and STV, much akin to the Irish electoral system, it has led to the elimination of a multiplicity of political forces and the emergence of two dominant parties. The MLP and the NP have alternated in government since 1962. Yet, as Duverger himself cautions, only investigation of the unique conditions in each country can determine the real origins of the two-party system in each case. Indeed, initially after the end of the World War II, the Maltese proportional system seemed to be obeying Duverger's law. But following a spate of unstable coalition governments in the 1950s, Maltese voters seemed to shift their preferences towards stable governance. Thus, the smaller parties gradually lost support to the two bigger political formations, the NP and the MLP. By 1966, only the NP and MLP were represented in the House of Representatives.

Apart from the electorate's apparent wish for stable governance, other factors may have been at play. First, the NP and MLP had been part of the political scene since the 1920 s and their roots ran deep in Maltese society, certainly deeper than the newer political formations which emerged after the end of World War II. In addition, some of the smaller parties set up in the 1950s and 1960s had splintered off from them. 
Also, Malta's small territorial size means that although it is subdivided into 13 electoral districts, electoral campaigns are carried out nationally, while individual candidates canvass on their own at district level in order to secure the maximum number of preference votes. The NP and MLP were the only two parties capable of spreading their presence nationally, initially by opening political clubs (Kazini) in Malta's towns and villages and subsequently by developing complex organizational structures led from their central headquarters.

Once the two main parties grew large enough in scale to surpass all their rivals, they were able to ensure that their message reached literally every citizen, often drowning everyone else's. Hence, they kept growing while the smaller parties began declining. Later and particularly after the mid-1980s, MLP-NP rivalry constrained both to embark on a number of new initiatives, such as increasing their penetration of the media, particularly electronic, thus further consolidating their duopoly. This made it more difficult for third parties to enter the arena.

Another obstacle faced by small parties is the wasted votes in each district, which in national elections count for very little. Keeping in mind that each electoral district is an independent unit, a party may obtain a substantive amount of votes nationally, but unless it is capable of securing a quota in one electoral district it cannot win a parliamentary seat. For example, in the 2003 election, the size of the quota in each of the 13 districts ranged from 3,379 to 3,787 . Thus a party obtaining around 33,000 votes (11.7 per cent) nationally, but which were more or less evenly spread among the 13 districts, thus failing to achieve a quota in any of them by the smallest of margins, would not win a seat in Parliament. In contrast, a smaller party with just 4,000 votes concentrated in one district would win one seat. These realities of the Maltese political scene and the operation of its proportional system discussed in this section should be kept in mind when discussing the election to the European Parliament.

\section{Party Performance}

In this election, the biggest surprise was the performance of the small green party, Alternattiva Demokratika, which fielded only one candidate, Professor Arnold Cassola, Secretary General of the Green Group in the EP. For the Nationalists, the result was their biggest upset following their successes in the 2003 referendum on EU membership and subsequent April election. The NP fought to maintain its overall majority at the polls and win three EP seats, hoping that the electorate would reward it for taking Malta into the EU. AD's good performance debilitated the NP's support and shattered its hopes. The NP's main rival, the opposition MLP, ran away with three seats but only because the Nationalists stumbled. Indeed, one of the major conclusions from this election is that many voters who had voted NP in the April 2003 election preferred to switch to $A D$ rather than to the MLP.

To gauge the significance of AD's success, it is worth recalling that while in the 2003 general election, this party obtained just 1,929 first count votes and gained no seats in the House of Representatives. In contrast, in the EP election it managed to take no 
fewer than 22,938 first preference votes. AD's electoral performance was better in NP strongholds than in the Labour ones. Data published by the Electoral Commission show that 69 per cent of AD's votes came from predominantly and traditionally NP districts, although it managed to improve its support across the national territory. Indeed, $\mathrm{AD}$ campaigned most strongly in predominantly Nationalist areas where potential voters were traditionally pro-EU. What is also interesting is that $\mathrm{AD}$, which normally performs better in local than in national elections, did much better in the EP election than in the local elections which took place on the same day. In the local elections it obtained 6.9 per cent of the vote in the districts it contested, as opposed to the 9.3 per cent it obtained in the EP election.

The election to the European Parliament was held concurrently with elections to renew a third of the Maltese local councils. The first local government elections were held in 1993 and 1994. A third of the local councils are renewed each year. In all, there are 68 local councils, 54 in Malta and 14 in the island of Gozo. The 2004 local council election involved 22 localities in Malta and Gozo. The turnout rate was 82 per cent, the same as the nationwide participation rate in the EP election. In comparison, in 2001 the voter participation rate in the same group of local councils was 71 per cent. It is thus possible that the EP election may have induced more voters to participate in local elections than would have perhaps been the case without it.

\section{Opinion Poll Forecasts}

To draw some conclusions from the EP election results, one needs to compare them with pre-poll public opinion and voter expectations. The opinion poll carried for The Sunday Times of Malta (STOM), published on 6 June 2004, yielded the following main results:

- 85 per cent intended to vote in the election

- 31 per cent refused to say how they were voting

- 36.5 per cent said that they would be voting for the NP

- 21.6 per cent said they would vote for the MLP

- 9.0 per cent for $\mathrm{AD}$

- 1.6 per cent said they would vote for independents.

The turnout indicated in the STOM survey more or less materialized. The actual turnout was 3 per cent lower than predicted. The high number of voters ( 31 per cent) who were reluctant to indicate their voting preferences prior to the poll can be seen with hindsight to have been indicative of the 'abnormal' manner in which some voters intended to vote. The 9 per cent support for $\mathrm{AD}$ materialized: its candidate in fact obtained 9.3 per cent of the valid votes. As to the main issues on which voters were going to vote, these were clearly indicated by the 'Flash Eurobarometer' (Flash EB 161). The latter identified voters' main concerns as: unemployment (64 per cent), protection of the environment ( 45 per cent), pensions ( 44 per cent), economic growth ( 39 per cent), terrorism ( 20 per cent), crime (19 per cent) and joining the Euro (10 per cent). 
Table 22003 Election and Referendum, 2004 EP Election Results Compared

\begin{tabular}{lccc}
\hline & $\begin{array}{c}\text { Referendum on } \\
\text { EU membership } \\
\text { Date }\end{array}$ & $\begin{array}{c}\text { General } \\
\text { election } \\
12.04 .2003\end{array}$ & $\begin{array}{c}\text { European Parliament } \\
\text { election } \\
12.06 .2004\end{array}$ \\
\hline 1. Registered voters & 297,881 & 297,930 & 304,283 \\
2. Votes cast and as & $270,650(90.9 \%)$ & $285,122(95.7 \%)$ & $250,691(82.4 \%)$ \\
$\quad$ a \% of registered & & & \\
$\quad$ voters in brackets & 266,722 & 282,213 & 245,722 \\
3. Valid votes cast & 89.54 & 94.72 & 80.75 \\
4. As a \% of registered voters & $143,094(52.9 \%)^{*}$ & na & na \\
$\quad$ Yes & $123,628(45.7 \%)^{*}$ & na & na \\
$\quad$ No & $3,928(1.5 \%)^{*}$ & $2,909(1.0 \%) *$ & $4,969(2.0 \%)^{*}$ \\
$\quad$ Invalid & na & $146,172(51.8 \%)^{* *}$ & $97,688(39.8 \%)^{* *}$ \\
Nationalist Party & na & $134,092(47.5 \%)^{* *}$ & $118,983(48.4 \%)^{* *}$ \\
Labour Party & na & $1,929(0.7 \%)^{* *}$ & $22,938(9.3 \%)^{* *}$ \\
Alternattiva Demokratika & na & $20(0.0 \%)^{* *}$ & $6,113(2.5 \%)^{* *}$ \\
Others & & &
\end{tabular}

*Percentages indicated as of votes cast.

**First count votes and as a percentage of valid votes.

The last in this series of EB 161 surveys, conducted between 31 May and 2 June, gave some indicators as to how Maltese voters looked upon the candidates contesting the elections. Maltese voters attached most importance to how candidates perceived national ( 81 per cent) and European issues ( 80 per cent). Third came the personalities of the candidates. On all of these issues, the score for Malta was well above the EU-25 average. On the other hand, the most salient reason cited by those indicating that they would be abstaining was primarily the belief that the vote would not change anything (61 per cent). Only 24 per cent said they were against Europe, the EU and European construction. This was 3 per cent higher than the EU-25 average. More than three quarters of respondents indicated that they were sufficiently informed in order to choose whom to vote for in the election-the EU-25 average was 48 per cent.

Broadly speaking then, the results of the EP election in Malta seem to confirm many of the forecasts and results of opinion polls conducted both in Malta as well as at the EU level such as the Flash EB 161 quoted here. Naturally, surveys conducted closer to polling day proved to be more accurate.

\section{Issues, Candidates and the Campaign}

What caused voters to desert the NP and vote for $\mathrm{AD}$ ? Two main reasons could be advanced to explain this behaviour. The first is that they wanted to send a message of protest to the governing NP. The second is that AD's campaign convinced voters. Most likely, both factors are important in explaining the result. Voters consider AD's candidate, Dr Cassola, to be knowledgeable of EU affairs. Besides being Secretary General of the Greens in the EP, he had also taken a prominent role in the campaign in 
favour of EU membership. Indeed the pre-election polls analyzed in the previous section show how important this was for voters.

This argument is strengthened by the fact that as shall be shown below, it was not Mr Cassola alone who was rewarded for his 'Europeanness'. Indeed all the candidates who were eventually elected to the EP fell into this category, particularly the NP's Simon Busuttil who polled no fewer than 58,899 first count votes, thus surpassing the quota by 17,945 . A lawyer by profession, a graduate in European Studies from Sussex University and a former Secretary General of the European Movement (Malta), Dr Busuttil had also headed the Malta-EU information Centre (MIC) and had formed part of the membership negotiating team. His runner up in the NP pack with 8,782 votes was Mr David Casa who had headed the Nationalist Party's 'yes' campaign. Eventually Mr Casa inherited enough preferences to clinch the Nationalist's second seat on the 17th count. The third runner up on the NP side was Dr Joanne Drake, a graduate of the College of Europe in Brussels, an EU law specialist and also a prominent activist in the 'yes' campaign. Dr Drake could probably have taken the third seat for the NP had it not been for AD's good performance.

On the Labour side it is important to underline the fact that Labour voters seem to have rewarded those candidates who in their eyes were most favourably inclined towards the EU. The front runner, Mr Joseph Muscat, a graduate in European Studies from the University of Malta, obtained 36,958 preference votes and was eventually elected. The other two MLP candidates to be elected, namely Dr John Attard Montalto, a Member of the House of Representatives and Mr Louis Grech, a former Chairman of the national airline, AirMalta, certainly did not possess the image of being strong opponents of Malta's EU membership.

Dr Attard Montalto had been 'rumoured' to be favourable to Malta's EU membership at the height of the MLP's 'no' campaign during which he had certainly kept a low profile. During the EP election campaign, the NP tried to undermine Mr Grech's credibility by insinuating that indeed he may not have toed the MLP line by voting 'no' in the referendum. This did not hurt Mr Grech. It must also be kept in mind that the MLP's November 2003 Conference, which selected the candidates for the EP election, had rejected the most extreme anti-membership hardliners. These included Ms Sharon Ellul Bonici, one of the most vocal 'no' campaigners, who performed most dismally in the selection phase.

Overall, judging from the credentials of the elected candidates, it is clear that Maltese voters gave due importance to personality as well as to the candidates' perceived knowledge of EU affairs. Seasoned politicians, including two former ministers, neither of whom was strongly associated with the EU issue, failed to be elected in spite of their undoubtedly deeper public roots.

The Nationalist Party was expected to take the lead in this campaign but failed to do so, mainly because it had to confront a number of internal changes in the party and government which crucially diverted its attention from the EP elections throughout February and March. These changes began to unfold following the resignation, on 7 February, of party leader and Prime Minister, Dr Eddie Fenech Adami, on reaching 
the age of 70 . The resignation led to a three-way leadership contest involving three Cabinet ministers. Eventually, Dr Lawrence Gonzi was elected Party leader by a comfortable margin and took the oath of Prime Minister on 23 March. With that major challenge out of the way, the NP Executive proceeded to select the EP election candidates who were officially announced on 2 April. In addition, there was widespread speculation that the President of the Republic, Dr Guido de Marco, a former Foreign Minister who had launched the Maltese membership application in 1990, and whose presidential term of office came to a close at the end of March, was also weighing whether to contest the EP election. This may have also caused the NP to delay the announcement of candidates.

In contrast, the NP's two other political rivals were not sitting idly by. The MLP chose three of its candidates in November 2003 and five more in February 2004, while AD had indicated Arnold Cassola as its candidate in the summer of 2003. Thus both the AD and the MLP began campaigning vigorously much before the NP finally entered the race.

During the election campaign, the NP stressed that MEPs elected in its name would form part of the EPP, the largest political group within the European Parliament. Thus, the party implied that by supporting its candidates, voters would enhance Malta's ability to achieve its national aims in the EU. The NP focused its guns on the MLP's recent record on the EU, reminding voters that the MLP had opposed membership both in the referendum and in the 2003 election campaign. This approach was not only intended to discredit the MLP on Europe. It was also hoped to pit the party leadership, which has pragmatically accepted the reality of EU membership, against the extremist minority within the party. The latter had constituted the backbone of the anti-EU Campaign for National Independence (CNI) and Front Maltin Inqumu (Arise Maltese Front) led by two former MLP leaders and Prime Ministers. These tactics were not successful in denting the MLP's performance, since turnout in most Labour strongholds tended to be slightly higher than the national average. However, it may have succeed in preventing the NP from focusing upon the probably more rewarding EU issues and the EPP's political programme, both of which featured only marginally in its repertoire.

As the campaign got under way, the NP also became alarmed by the results of its own unpublished voter attitude polls, which showed that AD's Arnold Cassola had begun to bite deeply into its support, thus endangering the NP's ability to elect three MEPs. To prevent this, the NP decided to attack Mr Cassola's credibility by accusing him of belonging to a Party which actively supported the legalization of abortion. In a predominantly Catholic country like Malta, where the vast majority of voters are against abortion, this tactic could have had a devastating effect. The NP's move forced $\mathrm{AD}$ to institute libel proceedings against leading NP candidates and party officials, eliciting counter legal action by the NP. The NP claimed in reply that it was not enough for someone to oppose abortion if at the same time he was part of a European party that included the legalization of abortion among its guiding principles. On such a fundamental issue, one had either to fight to change the stand of the party or else re-consider his stand within the group. 
This public outburst on abortion came as a surprise, considering that many viewed the issue as having been closed from an EU perspective. The government itself had safeguarded the Maltese position on abortion by insisting on the inclusion of the necessary safeguards within the Act of Accession. Voters who had already decided to vote for $\mathrm{Mr}$ Cassola found it hard to accept that his political affiliations could realistically lead to the introduction of abortion in Malta. AD further stressed that Cassola himself had made it publicly clear on many occasions, including in a letter he had sent to the European Greens when he took up the post of Secretary General, that he was against abortion. The court cases begun at the start of the campaign were not concluded before polling day and later $\mathrm{AD}$ abandoned the court procedures and the NP officials went free. Also, following the initial outburst and the initiation of the court proceedings the issue soon fizzled out.

Another tactic employed by the NP was to explain to its supporters that a vote for AD's candidate could unwittingly help the socialists secure their third seat. But the NP left this explanation to the eleventh hour, by which time most voters had already made up their mind on how they were going to vote. The intention behind the NP's tactic may have been to sow enough doubts and panic to entice many stray voters to return to the fold-the rationale of course being that uncertain and confused voters would normally play safe and vote as they had always voted. The tactic did not have the desired effect and the NP's gloomy forecast in fact materialized. In addition, not only did the NP fail to clinch the third seat, but $\mathrm{AD}$ failed to secure enough preferences to win the seat for itself.

An electoral pact between the two sides, in which both parties would have urged their supporters to continue giving their preferences to the other Party after voting for their candidates, could have produced a situation in which $\mathrm{AD}$ or the NP inherited enough preferences to beat the MLP for the third seat. Mutual antagonism ran so high between the NP-AD in the early stages of the EP campaign, notwithstanding that both had campaigned in favour of EU membership in the 2003 referendum and national election, that both sides were blinded to the advantages of such an electoral pact-and the implications if they failed to agreed.

For its part, the MLP was more inclined to focus its campaign on domestic political issues. Since winning the 2003 general election, the government has been promoting an economic re-structuring programme which has led to some political dissatisfaction. The most important parts of this programme shall be discussed later on; however, it is important to point out that the MLP did its best to capitalize on this dissent and the uncertainties that it generated. Thus, the MLP's campaign focused mostly on domestic issues and specifically on unemployment, environmental protection and pension reform, the issues which the public opinion polls had shown voters to be most sensitive about.

However, the MLP was also beset by a set of internal difficulties. The party had campaigned vigourously against EU membership for more than a decade. Following the 2003 referendum and election results, which signified that the Maltese electorate had twice rejected its stand on membership, party officials began to argue that 
the Maltese people had in fact decided the membership question and that this was no longer a political issue. The General Conference of the Party was convened in the summer of 2003 to approve this new policy on Europe, which it did, and in September 2003, the MLP was asked to join the Party of European Socialists (PES) as a full member and was accepted in November. The PES Congress ratified this decision in April 2004. Having completed all these tasks, the MLP proceeded to select its candidates for the EP elections. But 10 years of concerted anti-EU membership rhetoric had nurtured within the MLP a strong anti-EU movement. Most of its members also became active within the Campaign for National Independence (CNI) led by former MLP leader and prime minister, Karmenu Mifsud Bonnici, and the Front Maltin Iqumu (Arise Maltese Front) led by former MLP leader and prime minister, Dom Mintoff. The MLP's main fear was therefore that a substantial part of its traditional electorate would not participate in the EP elections, thus making it easier for the NP to secure three seats.

For this reason, it was in the MLP's interest to divert attention from EU to national issues in an effort to transform the election into a test of approval for the government by focusing on unemployment, the environment, prices and pension reform. It succeeded in this task thanks also to the NP's dogged resistance to debating real European issues and their possible effects on Malta. Thus, traditional Labour voters inclined to abstain from voting because this was after all a 'European' election were induced to vote to show their disapproval of government policy. As a result, voter turnout in predominantly MLP areas was slightly higher than the national average, while turnout in predominantly Nationalist areas was at or lower than the national average, reflecting some Nationalist disgruntlement with their party's performance in government.

It has also been speculated that the MLP wished to use the election result to strengthen the internal position of its leader. Alfred Sant had successfully warded off challenges to his leadership and was reconfirmed in his post soon after the 2003 election, despite having led his party to three successive defeats in three main national polls: the 1998 and 2003 elections and the referendum on EU membership. However, the EP election result showed that voters deserting the NP did not switch to the MLP but to $\mathrm{AD}$, which also implies that had the trend been repeated in a general election, the MLP would still face difficulties in securing an overall majority.

The most serious cause of disgruntlement with the NP and the government resulted mostly from the effect of the economic restructuring measures, whose implementation gathered momentum after the 2003 election. Many of these long-delayed changes began to be implemented in state-owned loss-making companies such as the dockyards, the national airline AirMalta and the Public Broadcasting Services (PBS). Most of these measures involved layoffs, the downward adjustments of incomes and/or early retirement schemes. In the case of the ship building and ship repair yards, they accounted for a sudden 2.3 per cent jump in the government debt as the state absorbed the yards' liabilities as part of the restructuring package. In some cases, such as the state-owned Gozo Channel, the shipping company operating the ferry service linking 


\section{R. Pace}

the island of Gozo to Malta, the government increased passenger and vehicle tariffs in a bid to cut losses. The latter reform did not go down well with inter-island commuters and Gozitans in particular. Meanwhile, in the social domain, the government has started grappling with pension and welfare reforms.

On some other issues the government betrayed hesitancy in confronting problems, thus projecting an image of ineptness in taking timely decisions. The Minister of Health delayed the introduction of a smoking ban in places of entertainment (bars and restaurants) following strong resistance by the association representing the owners of such establishments. Another issue on which the government appeared to be indecisive was the question of relocating a site for a controlled landfill to absorb urban waste. Both this and the smoking ban debacle also worked in AD's favour.

In addition, public finances were running out of control following a sizeable deterioration in the fiscal deficit. Indeed, the general government deficit increased from 5.7 per cent of GDP in 2002 to 9.7 per cent of GDP in 2003. Government debt to GDP ratio rose from 61.7 per cent of GDP in 2002 to 72 per cent of GDP in 2003. It is true that the task of addressing the public deficit has been made more difficult by a downward trend in economic activity provoked by the events of $9 / 11$ and the war in Iraq. In addition, there have been the growing burdens placed upon state administration and expenditure resulting from complying with the EU membership obligations. All these difficulties and the resultant increases in unemployment were quickly pounced upon by the MLP and used to criticize the government during the EP campaign.

An outcry was also raised during the campaign on the government's handling of illegal immigrants/refugees. This followed an Amnesty International Report (AI index: AFR 64/003/2004) published in May 2004, claiming that the majority of around 220 Eritrean illegal immigrants forcibly repatriated by Malta in 2002 had been imprisoned and tortured on return to their country and that many of them were still being held captive. The issue of the repatriation of the Eritreans was taken up by the Maltese press from around mid-May right up to election week. The Times carried a full-page news report on this issue on 5 June, just seven days before the ballot. The paradox regarding this issue is that the majority of Maltese people are very apprehensive of immigration (legal or illegal) due to Malta's small population and restricted territorial size. Working class fears have frequently been aired to the effect that immigrants take jobs which would otherwise be available for the Maltese unemployed. Yet the issue of the Eritrean repatriates was successfully employed to embarrass the government. After the election it also died out.

Also during the campaign, the MLP raised another issue by alleging inappropriate behaviour by the Minister of Foreign Affairs and calling for his resignation. The accusations against the minister were also made by The Times. Indeed the minister tendered his resignation a few weeks after the election.

\section{The Other Protagonists}

The EP election encouraged many single-issue independents, including some eccentrics and new political formations to enter the political arena. Some of these 
individuals claimed to represent a 'party', although lacking the organizational basis to qualify as such. The Alpha Party, campaigning in favour of legalizing divorce in Malta, probably selected that particular name for alphabetical reasons, in order to place itself at the head of the ballot sheet. In the end it obtained no more than 756 preference votes. The main thrust of Alpha was that Maltese legislation on divorce should be introduced to bring Malta into line with other EU member states.

Imperium Ewropa founded by N. Lowell, its only candidate, proposed a political programme based on Maltese ethnic purity and identity. The party's idea of Europe, as can be discerned from its public pronouncements, is one of a 'fortress Europe', an empire, defending itself against the threats of illegal immigration and the growth of non-European communities in its midst. Mr Lowell made a number of antiimmigrant and allegedly racist statements. After the election, the Broadcasting Authority accused a small privately owned TV channel of breaching the Broadcasting Act when it interviewed $\mathrm{Mr}$ Lowell and allowed him to make comments encouraging criminality which could lead to disorder and be offensive to public sentiment. It was also reported that the government had asked the police to institute criminal proceedings against Mr Lowell. The TV station was later fined Lm500 (Euros 1,150). Mr Lowell's tally of around 1,603 votes is small but indicative of the fact that extreme views on immigration and racial diversity may be growing.

Another independent candidate, Mr Carmelo Farrugia, contested the election on behalf of the 16,000 strong Federazzjoni Kaccaturi, Nassaba u Konservazzjonisti (Federation of Bird Hunters, Trappers and Conservationist-FKNK), of which he is secretary general. The FKNK candidate's battle cry was to safeguard hunting rules in Malta in order to ensure that hunters' and bird trappers' freedoms are not further pruned as a result of Malta's EU membership. He expected to poll most of his federation's members' votes but in the end gained just over a fifth of them. According to The Times of Malta (29 June 2004), he blamed his poor showing on discriminatory treatment by the media and in particular The Times which printed inappropriate photos' and which for example 'used a photograph of him which was 15 years old'. It has been argued in Malta that hunters and bird trappers had played an important role in the Nationalist Party's electoral defeat in 1996, resulting from a fear that EU membership would curtail hunting and trapping completely. The EP election showed that the hunters' and trappers' lobby had lost much of its fabled clout among the electorate and their weakness was exposed.

A Nigerian who is also a Maltese citizen, Damian Iwueke Chukwuemeka, also contested the election. He declared that if elected he wanted to represent minority groups and pledged to defend a long list of issues including women's rights, single parents, the right of gay couples to live as a family, children's rights and improved conditions of work for sportsmen and women. He also pledged to induce smokers and non-smokers to live happily together. Mr Iwueke believed that a sea change had occurred in Maltese politics as a result of EU membership and that what he was proposing was a new approach made possible by that change. His main slogan was 'Why Vote for Damian? Why Not?' Only 153 voters responded positively to his rhetorical question. 
The other political parties formed for the occasion included Kul Ewropa of C. H. Jones, son of a former politician who had founded Jones Party, which alas was not successful. Mr Jones's slogan was for a European Union based on a cultural integration. Kul Ewropa obtained 66 votes. The other novice to the Maltese political scene was the Christian Democratic Republican Party of Mr Mark Von Brockdorff which obtained 64 votes. Not much is known about this party's political stance towards the EU.

As can be concluded from this very brief survey of some of the 'non-mainstream' candidates, the EP elections encouraged many individuals with a cause, mostly a single issue, to try their luck. This does not normally happen in general elections when as has already been shown, the duopolistic control of the two major parties leaves little space for such freedom. However, in the case of the EP elections, these individuals were convinced that they stood a good chance of being elected —or they just wished to make a point. What is striking is that no Eurosceptic Party contested these elections, despite the strong anti-membership campaigning that had taken place in the run up to the 2003 election and referendum.

\section{Malta's European Prospects}

The evidence from the Maltese EP election shows that many of the factors that explain the high voter turnout in national and local elections were also at work in this election. In addition, local and not European issues dominated the campaign. This may be taken to mean that no significant shift has occurred in Maltese electioneering let alone in the Maltese political scene. However, the European election seems to indicate that on EU membership, Malta has turned the corner and a significantly larger part of the electorate is now solidly in favour of Malta's participation in the EU than was the case in 2003. If this shift is confirmed, this would not be the first time such a change has happened in Maltese history. The Maltese were similarly divided on independence and the closure of the UK military bases. But after both events, a national modus vivendi was achieved and a broader national support solidified behind both.

The fact that Malta's two main political parties and $\mathrm{AD}$ all support $\mathrm{EU}$ membership is of itself significant in mobilizing a substantive part of a very active electorate in favour of membership. This is confirmed by the most recent Eurobarometer survey prior to the EP election which shows that support for the EU has been steadily increasing in Malta. Further evidence comes from the fact that the candidates with the strongest European credentials performed best in the election, showing-as the opinion polls had forecast before the poll-that a majority of Maltese voters ( 80 per cent) attached a lot of importance to this fact.

If one had further to dissect the small combined vote of the independents and new political parties launched for the occasion, one would also arrive at the same conclusion. All were contesting on a European platform even if a markedly different paradigm of Europe than the EU, as shown in the case of Imperium Europa. Indeed, the common denominator of all the small parties and independents was that they were 
seeking a solution to their sectorial aims through the EU. None were out to dismantle it. The evidence suggests that Malta has indeed turned a new leaf on Europe.

The significance of this development is that Malta is likely to become a more consistent participant in the process of European integration. Though Maltese politicians from the two main political parties seem to lean more towards intergovernmentalist as opposed to 'federalist' approaches to European union, no serious objections to Europe's constitutional project have been forthcoming from the three main political formations. Malta has accepted the new qualified majority voting system and was pleased by the establishment of six EP seats as the minimum for every member state in the EP. However, a truly national debate on what kind of Europe the Maltese want has not really taken off. Before it does, it will be very difficult to draw politicians out to debate their concepts of Europe. Malta's new Foreign Minister, Dr Michael Frendo, who participated in the Convention before his ministerial appointment, is widely expected to raise the stakes in this domain. Meanwhile, the government has already indicated that it has no intention of submitting the Draft European Constitution to a referendum, which might have provided an opportunity for the initiation of such a debate.

Sensitivities become most acute when defence issues are involved: the announcement that Malta was joining the European Defence Agency elicited the MLP's immediate response that it would withdraw Malta if eventually elected to govern. With regard to joining the euro, the government has launched a very ambitious Convergence Plan, aiming to help Malta achieve the macroeconomic criteria of the Stability Pact by 2007. This is accompanied by a strong commitment to administrative reform and strengthening good governance. While the Nationalist Party's target is to join the euro at the earliest opportunity, the MLP's policy on this score is still unclear.

Malta's MEPs are expected to become full participants in the European political groupings to which they belong: NP in the EPP, MLP in the PES. Both Maltese parties enjoyed strong relations with their respective political groupings prior to Malta's membership of the EU, although arguably the PN's connections with the EPP have been stronger than those of the MLP with the PES. In the vote on the Commission President Designate, José Manuel Durão Barroso, the PN MEPs voted in favour while the MLP voted against, in line with the majority of PES MEPs. On the Draft EU Constitution Maltese PES members abstained-in difference to the PES position. The MLP will be deciding its position on the Constitution in July 2005 when the Maltese Parliament is also expected to vote on it. The Maltese MEPs are expected to be good members of their respective European groupings and would only find cause to differ with them on salient issues of defence and security policy which touch upon Malta's neutrality. The influence they can exercise on the EP will depend on the committees to which they are assigned, the level of commitment which they show and their readiness to immerse themselves in EU matters. Of the five MEPs elected, only one has ministerial and parliamentary experience. The others are on average young and untried but with a lot of drive. 
Turning back to the EP election results, it is clear that the NP was punished by voters, but the MLP did not appear to profit from this by picking up disgruntled NP voters. Indeed, an NP-AD electoral pact to encourage their supporters to continue to vote for each other's candidates after casting their party preferences could have robbed the MLP of its third seat albeit by a small margin. AD made a good showing but its failure to win a seat strengthened perceptions that it is unelectable. This may increase its difficulties in future elections. Had the NP focused on European issues, towards which the public mood was very positive, it might have performed better. The cost of missing out on this was the forfeiture of the third seat.

Lastly, the EP election was the first of its kind for Malta and, therefore, some of the conclusions reached here must be considered provisional until future verification. 